\title{
Is Psychological Capital A Form of Emotional Intelligence? \\ A research on University Students
}

\author{
Eylem Şimşek, Turkish Air Force, Turkey \\ Hakkı Aktaş, Istanbul University, Turkey
}

\begin{abstract}
Psychological capital (PsyCap) is defined as one's being hopeful, resistant, self-confident and optimistic (Luthans \& Youssef, 2004). Whereas emotional intelligence stated by Goleman (1998) as "the capacity for recognizing our own feelings and those of others, for motivating ourselves, and for managing emotions well in ourselves and in our relationships". Emotional intelligence is a combination of individuals' personal competence and social competence (Goleman, Boyatzis \& McKee, 2002). Both emotional intelligence and PsyCap has been evaluated as inner resources of positive outputs like success, satisfaction, well-being, health etc. But it is not clear to what extent emotional intelligence and PsyCap were similar. The purpose of this research is to examine the interaction between emotional intelligence and psychological capital by employing a quantitative approach of scientific inquiry. A demographic data sheet, Psychological Capital Questionnaire (Luthans et. al, 2007) and Emotional Competence Inventory (ECI, Boyatzis, Goleman \& Rhee, 2000) has been implemented. Correlation, and multiple regression techniques were conducted. Significant results revealed that PsyCap and emotional intelligence were significantly associated. The correlation between PsyCap and EI is $(\mathrm{r}=.540, \mathrm{p} \leq .01)$. Subfactors of EI, social awareness and self-awareness, explained $28.8 \%$ of the variance on PsyCap.
\end{abstract}

Keywords: Psychological capital, emotional intelligence, positive psychology, positive organizational behavior 


\section{Introduction}

The new positive psychology paradigm pointed out the importance of individual's well-being from a various perspectives. The efforts to increase not only performance, but also well-being and happiness leads to focusing on new phenomena, namely emotional intelligence and PsyCap. Positive psychology paradigm differs from previous approaches by giving importance to the happiness as much as pain, in order to increase individuals' happiness by improving their awareness and strengths (Seligman, 2007; Seligman et. al, 2005). Positive psychology is not focused on curing the people who are patient, in contrast increasing the happiness of normal individuals (Seligman, 2007). The positive psychology paradigm applied to psychology, social psychology, sociology, marketing, management and economy in a short period (Sirgy et. al., 2006). Emotional competence is "a learned capability based on emotional intelligence that results in outstanding performance at work" (Goleman, 1998b). PsyCap could be associated with emotional intelligence. The purpose of this study is to examine the interaction between emotional intelligence and psychological capital.

\section{Psychological Capital (PsyCap)}

Positive Organizational Behavior (POB), based on positive psychology, examined positive psychological resource capacities. Luthans et. al., (2001) underlined the importance of determination and application of required skills in the psychological and human resources from an individual oriented perspective. Positive psychological capital, including hope, resilience, self-confidence and optimism, should be measured to enhance performance and well-being of individuals (Luthans, Youssef, \& Avolio, 2007).

Some individuals perform better than others under stressful conditions. Organizational researchers generally focused on to determine the traits of higher performers. First studies explained these performance differences by general mental ability-intelligence levels (Hunter \& Hunter, 1984; Schmidt \& Hunter, 2000). PsyCap consists of four dimensions: “(1) having confidence (self-efficacy) (2) making a positive attribution (optimism) (3) persevering toward goals and redirecting paths to goals (hope) (4) when faced by problems sustaining and bouncing back (resilience) to attain success" (Luthans \& Youssef, 2004; Luthans, Youssef, \& Avolio, 2007, p.3). The PsyCap is mostly associated with overcome the psychological problems in order to find new solutions (cited in Simsek \& Sali, 2013). 


\section{Emotional Intelligence}

Some individuals could understand and evaluate themselves, others and manage the emotions, relationships, communication practices and performance scores better than others no matter how intelligent they are (Şimsek \& Aktaş, 2013). These differences were explained historically by social intelligence, multiple intelligence or emotional intelligence. Emotional intelligence was defined by Salovey and Mayer (1990) as "the ability to monitor one's own and others' feelings and emotions, to discriminate among them and to use this information to guide one's thinking and actions” (p. 189). Mayer and Salovey's (1997) model of emotional intelligence defines four discrete mental abilities: (1) perception of emotion, (2) use of emotion to facilitate thought, (3) understanding of emotion, and (4) management of emotion.

One of the most impressive books about emotional intelligence was written by Goleman in 1997, although related term social intelligence was used first in 1920's by Thorndike (1920). Goleman (1998a, p. 317) defined emotional intelligence as "the capacity for recognizing our own feelings and those of others, for motivating ourselves, and for managing emotions well in ourselves and in our relationships". Social skills require adeptness at inducing desirable responses in others (Goleman, 1998). Emotional intelligence reduced two dimensions: personal competence (self-awareness and self-management) and social competence (social awareness and relationship management). Goleman's model has been presented in Table 1 (Goleman, Boyatzis \& McKee, 2002).

Table 1. Goleman's framework of emotional competencies

\begin{tabular}{|c|c|c|}
\hline & $\begin{array}{c}\text { Self } \\
\text { Personal Competence }\end{array}$ & $\begin{array}{c}\text { Other } \\
\text { Social Competence }\end{array}$ \\
\hline Recognition & $\begin{array}{l}\text { Self-Awareness } \\
-\quad \text { Emotional self- } \\
\text { awareness } \\
-\quad \text { Accurate self- } \\
\text { assessment } \\
\text { - Self-confidence }\end{array}$ & $\begin{array}{l}\text { Social Awareness } \\
\text { - Empathy } \\
\text { - Service orientation } \\
\text { - Organizational } \\
\text { awareness }\end{array}$ \\
\hline Regulation & $\begin{array}{l}\text { Self-Management } \\
\text { - Self-control } \\
\text { - Trustworthiness }\end{array}$ & $\begin{array}{l}\text { Relationship } \\
\text { Management } \\
\text { - Developing others }\end{array}$ \\
\hline
\end{tabular}




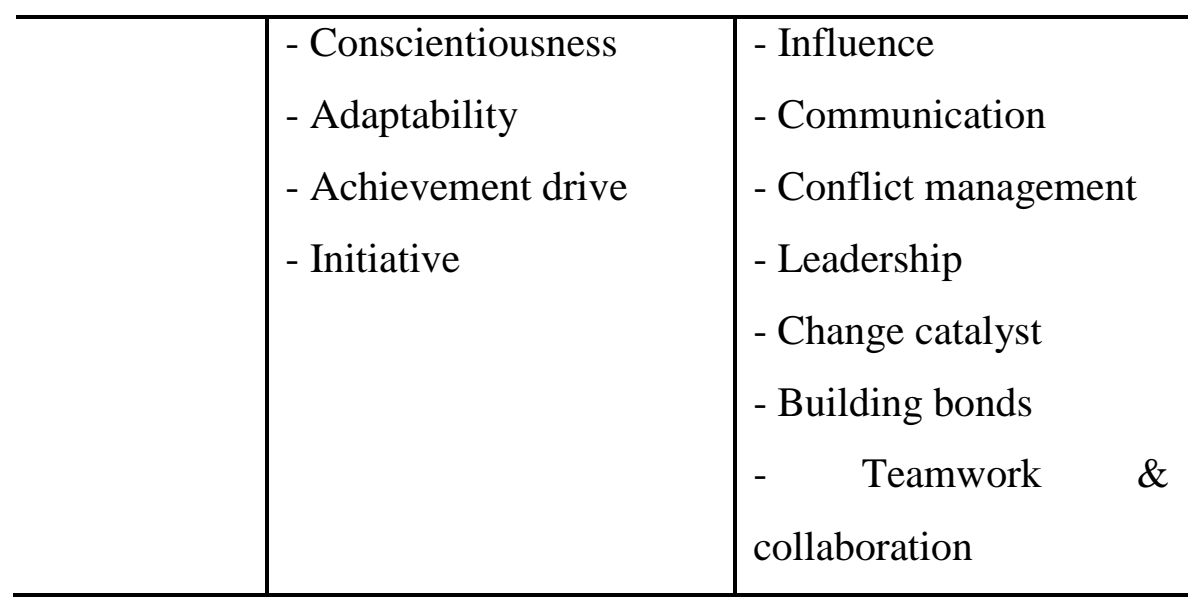

Individuals with higher emotional intelligence were found to experience more positive life events than others. Individuals with higher level EI manage their life better than lower ones. (Goleman, 1998a). The positive results of emotional intelligence were higher leadership performance (Palmer, Walls, Burgess, \& Stough, 2001), work performance (Khokhar \& Kangri, 2009), successful career in the organization (Salovey \& Mayer, 1990). Emotional intelligence has similarities with PsyCap in terms of evaluating and solving problems, developing different perspectives to a problematic situation. Self-awareness, managing emotions, self-motivation, empathy and managing relationships were basic concepts of emotional intelligence.

There are only a few studies focusing on the PsyCap and emotional intelligence relationship. Tugade and Fredrickson (1990) found that resilient individuals use positive emotions to bounce back from negative emotional experiences. Resilient people find positive meaning in negative circumstances. Ignat (2010) found positive and significant relationships between emotional intelligence and self-efficacy, high life satisfaction, a healthy way of coping with stress. Tomer (2005) evaluated both personal capital and emotional intelligence from economic perspective as an increasingly important intangible source. Mellão and Mónico's (2013) studied direct relationship between PsyCap and emotional intelligence in Portugal. They pointed out as a significant and high correlation between two variables. Malik and Masood's (2015) also found significant correlations between PsyCap and emotional intelligence $(r=.599)$. The main purpose of this study is to investigate the association of PsyCap with emotional intelligence and the research questions are given below:

1. What are the levels of PsyCap as an emotional intelligence? 
2. What is the correlation between PsyCap as an emotional intelligence?

3. How much of the PsyCap variance is explained by emotional intelligence?

\section{Research Method}

In this study a quantitative approach of scientific inquiry, descriptive, relational, and comparative models were used for exploring the interactions between PsyCap and emotional intelligence. The research model was illustrated in Figure1.

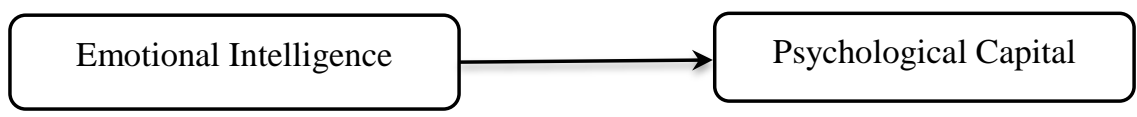

Figure 1: Research Model

\section{Research Sample}

The working sample consisted of 400 undergraduate students in a Public University in İstanbul. Data was collected from 176 individuals. 6 cases were deleted due to missing data and being outliers. After excluding missing values and outliers, data for 170 cases were analyzed. Regression assumption, normality, linearity, multicollinearity were tested.

\section{Research Instruments}

Emotional Competence Inventory (ECI)-Version 2: Inventory, 5 point Likert type with 72 items, was developed by Boyatzis, Goleman and Rhee (2000). Tuna (2008) translated into the Turkish in his doctoral study. Items numbers and Cronbach alphas for dimensions are given respectively: self-awareness ( 8 items, 0.622); self-management (24 items, 0.819), social awareness (12 items, 0.576), relationship management (24 items, 0.804).

PsyCap Questionnaire: Questionnaire, consisted of totally 24 items with a 6 point Likert type each, was developed by Luthans et al. (2007) and Çetin \& Basım (2012) translated into Turkish. Items numbers and Cronbach alphas for each dimensions are given respectively: hope (4 items, 0.598); resilience (5 items, 0.776); self-efficacy (6 items, 0.773); optimism (6 items, 0.883).

Procedures: The questionnaires were filled by undergraduate students by online and paperpencil. Pearson Correlation and Regression analyses were reported and the results discussed in context of the literature. 


\section{Results}

\section{Descriptive Statistics}

The means and standard deviations of the emotional intelligence (self-awareness, selfmanagement, social awareness, relationship management) and PsyCap (hope, resilience, selfefficacy and optimism) scores were illustrated at Table 2.

Table 2. Descriptive Statistics

\begin{tabular}{|r|c|c|c|c|c|c|c|c|c|c|}
\hline & Resistant & Hopeful & Optimistic & $\begin{array}{c}\text { Self } \\
\text { Confident }\end{array}$ & $\begin{array}{c}\text { Self } \\
\text { Awareness }\end{array}$ & $\begin{array}{c}\text { Self } \\
\text { Management }\end{array}$ & $\begin{array}{c}\text { Social } \\
\text { Awareness }\end{array}$ & $\begin{array}{l}\text { Relationship } \\
\text { Management }\end{array}$ & PsyCap & ECI \\
\hline M & 4,03 & 3,92 & 3,73 & 3,85 & 4,41 & 4,43 & 4,55 & 4,35 & 3,88 & 4,44 \\
\hline SD &, 66 &, 63 &, 72 &, 61 &, 63 &, 49 &, 53 &, 51 &, 56 &, 47 \\
\hline Min. & 1,00 & 1,50 & 1,33 & 1,17 & 2,75 & 3,13 & 3,17 & 3,13 & 1,25 & 3,09 \\
\hline Max. & 6,00 & 5,00 & 5,67 & 5,67 & 6,00 & 5,58 & 5,92 & 5,83 & 5,52 & 5,74 \\
\hline
\end{tabular}

\section{Correlation Analysis between PsyCap and Emotional Intelligence}

The interactions between PsyCap and emotional intelligence were evaluated by Pearson correlation coefficients. Pearson Correlation Coefficients are given in Table 3 below.

Table 3. Pearson Correlation Coefficients between PsyCap \& Emotional Intelligence

\begin{tabular}{|c|c|c|c|c|c|c|c|c|c|c|}
\hline & (1) & (2) & (3) & (4) & (5) & (6) & (7) & (8) & (9) & (10) \\
\hline (1) Resistant & 1 & $608^{* * *}$ &, $509^{* * *}$ &, $665^{* *}$ & ,339** &, $361^{* *}$ &, $459^{* * *}$ &, $375^{* *}$ & ,819** &, $434 * *$ \\
\hline (2) Hopeful & & 1 &, $569^{* * *}$ &, $711^{* * *}$ &, $405^{* * *}$ &, $365^{* *}$ &, $439^{* * *}$ & $456^{* *}$ &, $844 * *$ & ,473** \\
\hline (3) Optimistic & & & 1 &, $699^{* *}$ &, $376^{* *}$ &, $402^{* *}$ &, $425^{* * *}$ &, $389^{* *}$ &, $830 * *$ &, $451 * *$ \\
\hline (4) Self Confident & & & & 1 &, $395^{* *}$ & $412^{* * *}$ &, $434^{* *}$ &, $422^{* *}$ & ,901** & ,472** \\
\hline (5) Self Awareness & & & & & 1 &, $652^{* *}$ &, $606^{* * *}$ &, $747^{* *}$ & ,446** & $871 * *$ \\
\hline $\begin{array}{l}\text { (6) Self- } \\
\text { Management }\end{array}$ & & & & & & 1 &, $681^{* *}$ &, $783^{* *}$ &, $454 * *$ &, $875 * *$ \\
\hline $\begin{array}{l}\text { (7) Social } \\
\text { Awareness }\end{array}$ & & & & & & & 1 &, $729^{* *}$ &, $518 * *$ &, $852 * *$ \\
\hline $\begin{array}{l}\text { (8) Relationship } \\
\text { Management }\end{array}$ & & & & & & & & 1 &, $483 * *$ &, $922 * *$ \\
\hline
\end{tabular}




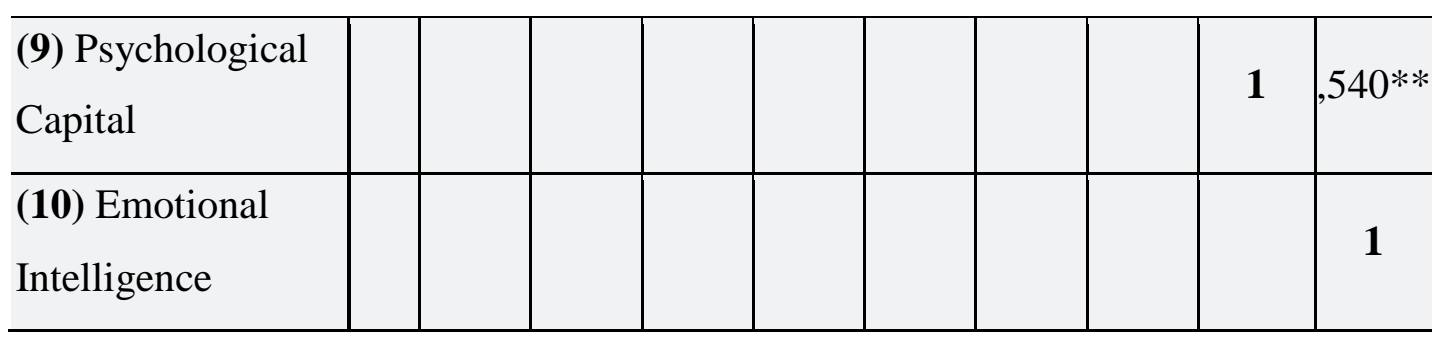

**. Correlation is significant at the 0.01 level (2-tailed).

As shown on the Table 3, all of the dimensions of PsyCap are positively correlated with all the dimensions of emotional intelligence. The range between two variables were .339-.459. The highest correlation were between resistant (PsyCap) and social awareness (EI), ( $r=.459$, $\mathrm{p} \leq .01)$. The correlation between PsyCap and EI is $(\mathrm{r}=.540, \mathrm{p} \leq .01)$.

\section{Regression Analysis}

In order to predict PsyCap, four dimensions of emotional intelligence were regressed onto PsyCap, using stepwise regression. $\mathrm{R}$ was significantly different from zero, $\mathrm{R}=.544 ; \mathrm{F}(2,167)$ $=35,156 ; \mathrm{p}=.000$. Social awareness made the highest contribution to the prediction of PsyCap, explaining $26.4 \%$ of the variance. Both social awareness and self-awareness, explained $28.8 \%$ of the variance on PsyCap. Detailed regression results were presented in Table 4.

Table 4. Regression Analysis

\begin{tabular}{lcrc}
\hline \multicolumn{4}{l}{ Dependent Variable: Psychological Capital } \\
\multicolumn{1}{l}{ Independent } & $\boldsymbol{\beta}$ & $\boldsymbol{t}$ & $\boldsymbol{p}$ \\
Variable: & & & \\
$\quad$ Social Awareness & $\mathbf{0 . 3 9 2}$ & 4.801 & 0.000 \\
$\quad$ Self Awareness & $\mathbf{0 . 2 0 9}$ & 2.556 & 0.011 \\
$\boldsymbol{R}=0.544 ; \quad$ Adjusted $\boldsymbol{R}^{2}=0.288 ;$ & $\boldsymbol{F}=35,156 ;$ & $\boldsymbol{p}=0.000$ \\
\hline
\end{tabular}

The results demonstrated that emotional intelligence explained significantly high variance on PsyCap. As given above Table, $\beta$ coefficients of Social Awareness $(0,392)$ and Self Awareness $(0,209)$ are statistically meaningful. So the regression equation for PsyCap=1,206 + $0.392 \times$ Self Awareness + $0.209 \times$ Social Awareness. 


\section{Discussion}

The aim of this study was to explore the association between emotional intelligence and PsyCap, considering both explains individual's capacity from different perspectives. Emotional Intelligence and PsyCap were relatively new phenomena with many positive outcomes in work and non-work life. PsyCap is hypothesed as being not independent from emotions. Luthans, Avolio, Avey and Norman (2007) claimed that PsyCap is more stable than the positive emotions and moods but less stable than core self-evaluation and the two personality traits. Luthans, Youssef and Avolio (2007) underlined that PsyCap could be potentially related to positive constructs like creativity, wisdom, well-being, flow, humor, gratitude, forgiveness, Emotional Intelligence, spirituality, authenticity, and courage.

The role of emotional intelligence on PsyCap was investigated, in a sample of university students. The sub-factors of PsyCap were resilience, hope, optimism, and self-efficacy. Emotional Intelligence's dimensions were personal competence (self-awareness and selfmanagement) and social competence (social awareness and relationship management). A positive and significant correlation was found between all dimensions of variables. The correlation between PsyCap and EI is $(\mathrm{r}=.540, \mathrm{p} \leq .01)$. The results were consistent with Malik and Masood's (2015) study in Pakistan and Mellão \& Mónico'ss (2013) study in Portugal. Regression analyses of this study were different from Malik and Masood's (2015) research in terms of the shifting independent and dependent variables in regression analysis. In this study, Emotional Intelligence explained 28.8\% of the variance on PsyCap. Whereas Malik and Masood (2015) regressed control variables (age, gender and organization) and PsyCap on Emotional Intelligence, explaining 25.8\% percent variance. All results confirms that PsyCap and Emotional Intelligence were relevant concepts.

This study has some limitations, focusing only the relationship between emotional intelligence and PsyCap. The effects of core self-evaluations and personality traits on emotional intelligence and PsyCap association could be tested. Moreover, research on outcomes of emotional intelligence and PsyCap association, like well-being, performance, positive work attitudes, behaviours, workplace spirituality, and psychological empowerment has been suggested. 


\section{References}

Avey, J. B., Wernsing, T.S., \& Luthans, F. (2008). Can positive employees help positive organizational change? Impact of psychological capital and emotions on relevant attitudes and behaviors. Journal of Applied Behavioral Science, 44, 48-70.

Boyatzis, R.E., Goleman, D., \& Rhee, K. (2000). Clustering competence in Emotional Intelligence: Insights from the Emotional Competence Inventory (ECI)s. In R. Bar-On and J.D.A. Parker (eds.), Handbook of Emotional Intelligence. San Francisco: JosseyBass, pp. 343-362.

Çetin, F. \& Basım, H.N. (2011). Psikolojik dayanıklılığın iş tatmini ve örgütsel bağlılık tutumlarındaki rolü. Işs, Güç; Endüstri İlişkileri ve Insan Kaynakları Dergisi, 13(3), 79-94.

Çetin, F., \& Basım, H.N. (2012). Örgütsel psikolojik sermaye: Bir ölçek uyarlama çalışması. Amme İdaresi Dergisi, 45(1), 121-137.

Goleman, D. (1998a). Working with emotional intelligence. London, Bloomsbury Publishing.

Goleman, D. (1998b). What makes a leader? Harvard Business Review, NovemberDecember.

Goleman, D., Boyatzis, R. E., \& McKee, A. (2002). Primal leadership: Realizing the power of Emotional Intelligence. Boston: Harvard Business School Press.

Hunter, J.E., \& Hunter, R.R. (1984). Validity and utility of alternate predictors of job performance. Psychological Bulletin, 96, 72-98.

Ignat, A.A. (2010). Teachers' satisfaction with life, Emotional Intelligence and stress reactions. Petroleum - Gas University of Ploiesti Bulletin, Educational Sciences Series, 62(2), 32-41.

Khokhar, C.P. \& Kangri, G. (2009). Emotional Intelligence and work performance among executives. Europe's Journal of Psychology, 1.

Luthans, F., \& Youssef, C.M. (2004). Human, social, and now positive psychological capital management: Investing in people for competitive advantage. Organizational Dynamics, 33(2), 143-160.

Luthans, F., \& Youssef, C.M. (2007). Emerging positive organizational behavior. Journal of Management, 33(3), 321-349.

Luthans, F., Avolio, B.J., Avey J.B., \& Norman S.M. (2007). Positive PsyCap: Measurement and relationship with performance and satisfaction. Leadership Institute Faculty 
Publications (Paper 11). Retrieved on 10 April 2016 from http://digitalcommons.unl.edu/ leadershipfacpub/11.

Luthans, F., Luthans, K., Hodgetts, R., \& Luthans, B. (2001). Positive approach to leadership (PAL): Implications for today's organizations. Journal of Leadership Studies, 8(2), 320.

Luthans, F., Youssef, C.M. \& Avolio, B.J. (2007). Psychological capital: Developing the human competitive edge. New York, NY, US: Oxford University Press

Malik, S.Z. \& Masood, S. (2015). Emotional Intelligence and resistance to change: Mediating role of psychological capital in telecom sector of Pakistan. Pakistan Journal of Commerce and Social Sciences, 9 (2), 485-502.

Mayer, J.D., \& Salovey, P. (1997). What is Emotional Intelligence? In P. Salovey \& D. J. Sluyter (Eds.), emotional development and Emotional Intelligence: Educational implications (pp. 3-34). New York, NY: Basic Books, Inc.

Mellão, N. \& Mónico, L.S.M. (2013). The relation between Emotional Intelligence and psychological capital of employees. International Journal of Developmental and Educational Psychology, 2(1), 545-550.

Michele, M., \& Fredrickson, B.L. (2004). Resilient individuals use positive emotions to bounce back from negative emotional experiences. Journal of Personality and Social Psychology, 86(2), 320-333.

Palmer, B., Walls, M., Burgess, Z. Stough, C. (2001). Emotional Intelligence and effective leadership. Leadership \& Organization Development Journal, 22(1), 5-10.

Salovey, P., \& Mayer, J.D. (1990). Emotional Intelligence. Imagination, Cognition and Personality, 9, 185-211.

Schmidt, F.L., \& Hunter, J.E. (2000). Select on intelligence. In E. Locke (Ed.), The Blackwell handbook of principles of organizational behavior: 3-14. Oxford, UK: Blackwell.

Seligman, M.E.P. (2007). Gercek mutluluk. Kalıcı doyum potansiyelinizi gelişstirmek için yeni olumlu psikolojinin kullanılması. Ankara: HYB.

Seligman, M.E.P., Steen, T.A., Park, N. \& Peterson, C. (2005). Positive psychology progress: Empirical validation of interventions. American Psychologist, 60, 410-421.

Şimşek, E. \& Aktaş, H. (2013). The evaluation of communication skills and Emotional Intelligence in the context of work values. International Conference on Communication, Media, Technology and Design Conference Proceedings. 
Şimsek, E. \& Balaban-Sali, J. (2014). The role of Internet addiction and social media membership on university students' psychological capital. Contemporay Educational Technology, 5(3), 239-256

Sirgy, J.M., Michalos, A.C., Ferris, A., Easterlin, R., Patrick, D., \& Pavot, W. (2006). The quality-of-life (QoL) research movement: Past, present, and future. Social Indicators Research, 76, 343-466.

Tomer, J.F. (2005). Personal capital and emotional intelligence: An increasingly important intangible source of economic growth. Eastern Economic Journal, 3, 453-70.

Tugade, M.M. \& Fredrickson, B.L. (2004). Resilient individuals use positive emotions to bounce back from negative emotional experiences Pers Soc Psychol., 86(2), 320-33.

Tuna, Y. (2008). Örgütsel iletişim sürecinde yöneticilerin duygusal zekâlarının değerlendirilmesi. Yayımlanmamış Doktora tezi. Eskișehir: Anadolu Üniversitesi. 